\title{
Polymorphisms of the nucleolus organizing regions in Loricaria cataphracta (Siluriformes, Loricariidae) of the upper Paraguay River basin indicate an association with transposable elements
}

\author{
F.E. Porto ${ }^{1}$, B.S. Gindri ${ }^{2}$, M.M.R. Vieira ${ }^{2}$, L.A. Borin ${ }^{1}$, \\ A.L.B. Portela-Castro ${ }^{1}$ and I.C. Martins-Santos ${ }^{1}$ \\ ${ }^{1}$ Departamento de Biotecnologia, Genética e Biologia Celular, \\ Universidade Estadual de Maringá, Maringá, PR, Brasil \\ ${ }^{2}$ Universidade Estadual de Mato Grosso do Sul, \\ Unidade Universitária de Coxim, Coxim, MS, Brasil \\ Corresponding author: F.E. Porto \\ E-mail: ferreroporto@yahoo.com.br
}

Genet. Mol. Res. 13 (1): 1627-1634 (2014)

Received December 21, 2013

Accepted June 29, 2013

Published March 12, 2014

DOI http://dx.doi.org/10.4238/2014.March.12.15

\begin{abstract}
A cytogenetic analysis of Loricaria cataphracta revealed a diploid number of $2 n=64$ chromosomes, distributed as 12 metacentric +8 submetacentric +2 subtelocentric +42 acrocentric, with a fundamental number of 86. Analysis of the nucleolus organizing region (NOR) using silver nitrate impregnation and fluorescence in situ hybridization (18S rDNA probe) techniques showed intra-population chromosomal polymorphism that could be classified into five different patterns (I to V), involving four pairs of chromosomes (8, 9, 12, and 13). In pattern I, the NOR was located in pair 12, whereas in pattern II, the NOR was detected in pair 8; these two patterns were characterized as a simple-NOR system. A multiple NOR system was evident in the other patterns (III, IV, and V). In pattern III, the NOR was located in
\end{abstract}


only one of the homologs of pairs 12 and 8 , and in patterns IV and V, the NOR was observed in pair 12 and in only one of the homologs of pairs 9 and 13, respectively. In addition, C-band analysis also showed this pattern of variation, and characterized a polymorphism in relation to the constitutive heterochromatin; the composition of this region was GC-rich (positive $\mathrm{CMA}_{3}$ ) and 4',6-diamidino-2-phenylindole negative. Transposition of NOR sites for mobile elements is suggested to explain this polymorphism.

Key words: Ag-NOR; C-band; Cytogenetics; FISH; NOR patterns; Loricaria cataphracta

\section{INTRODUCTION}

Loricaridae is one of the largest families of fish from the Neotropics, comprising approximately 834 species distributed across 96 genera (Eschmeyer and Fong, 2012), and consists of six subfamilies: Hypoptopomatinae, Hypostominae, Loricariinae, Neoplecostominae, Lithogeneinae, and Delturinae (Reis et al., 2006). Despite the fact that the subfamily Loricariinae is one of the most diversified among all Loricariids, being composed of approximately 270 species of catfish (Eschmeyer and Fong, 2012), cytogenetic studies of this subfamily are scarce. However, Loricariinae shows large karyotype variability, with diploid numbers ranging from $2 n=36$ chromosomes in Rineloricaria latirostris (Giuliano-Caetano, 1998) to $2 n=74$ chromosomes in Sturissoma cf. nigrirostrum (Artoni and Bertollo, 2001).

The genus Loricaria Linnaeus, 1758, contains 15 valid species (Thomas and Rapp PyDaniel, 2008; Thomas and Pérez, 2010), and cytogenetic studies have been conducted in eight species of this genus, revealing variation in the chromosome number in this fish group, ranging from $2 \mathrm{n}=52$ in Loricaria sp (Oliveira et al., 1998) to $2 \mathrm{n}=64$ in Loricaria cataphracta (cited as Loricaria carinata, Roncati et al., 1999) and Loricaria sp (Scavoni and Júlio-Jr., 1994). Moreover, supernumerary chromosomes were also detected in both Loricaria sp and L. prolixa, which are considered to be the first reports of these chromosomes in the subfamily Loricariinae (Scavone and Júlio-Jr., 1994).

Nucleolus organizing regions (NORs) have been extensively studied in the subfamily Loricariinae, and the majority of its species show a simple-NOR system, indicating conservative evolution for this group. However, multiple NOR systems have also been characterized in Rineloricaria lanceolata (Porto, 2012) and Rineloricaria pentamaculata (Porto et al., 2011).

Polymorphisms of the NOR have been observed in some Loricariinae species, revealing inter- and intra-population variation, although the latter has been relatively rare (Galetti Jr., 1998). Several mechanisms have been proposed to explain these polymorphisms, including chromosomal rearrangements, gene expression variation, and transposable elements for postzygotic modifications and transposition of copies of rDNA cistrons, which are considered to be the main factors responsible for these variations in both the position and number of NORs (Galetti Jr. et al., 1995; Santi-Rampazzo et al., 2008).

Because cytogenetic data in the genus Loricaria are scarce, the objective of the present study was to analyze the karyotype of one L. cataphracta population and to describe intrapopulation polymorphisms of its NORs using different techniques: silver nitrate impregnation (Ag-NOR), fluorescence in situ hybridization (FISH; with an 18S rDNA probe), chromomycin $\mathrm{A}_{3}\left(\mathrm{CMA}_{3}\right), 4$ ',6-diamidino-2-phenylindole (DAPI), and C-band. 


\section{MATERIAL AND METHODS}

Seventeen specimens of L. cataphracta (Figure 1) obtained from the Córrego do Onça, a tributary of the Taquari River (upper Paraguay basin) in Coxim, Mato Grosso do Sul, Brazil, were analyzed.

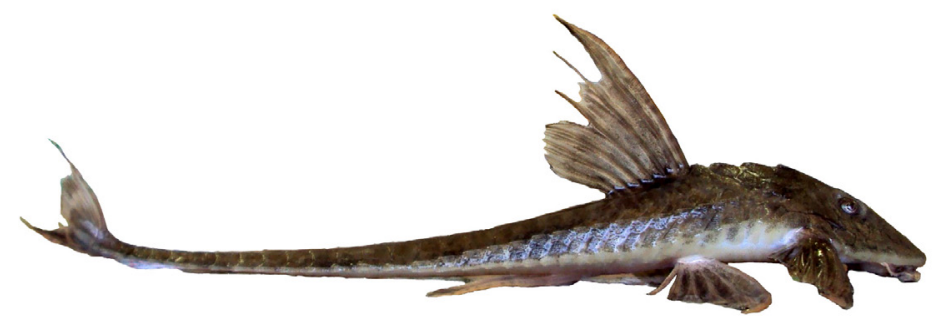

Figure 1. Loricaria cataphracta from Córrego do Onça, tributary of the Taquari River (upper Paraguay basin).

Mitotic chromosomes were obtained according to the air-drying technique described by Bertollo et al. (1978). NORs were detected using Ag-NOR (as described by Howell and Black, 1980) and by FISH, using 18S rDNA probes (amplified and cloned from Oreochromis niloticus) following the methodology described by Pinkel et al. (1986). The C-band technique (Sumner, 1972) was employed for constitutive heterochromatin analysis. Staining with the specific base fluorochromes, $\mathrm{CMA}_{3}$ and DAPI, was performed following the procedure described by Schweizer (1980). Identification of chromosomes was accomplished according to the arm ratio criteria (AR) suggested by Levan et al. (1964), as follows: metacentric chromosome (m: AR =1.00-1.70), submetacentric chromosome (sm: AR = 1.71-3.00), subtelocentric chromosome (st: $\mathrm{AR}=3.01-7.00)$, and acrocentric chromosome (a: $\mathrm{AR}>7.01$ ).

\section{RESULTS}

L. cataphracta specimens showed a diploid number of $2 n=64$ chromosomes with a karyotypic formula of $12 \mathrm{~m}+8 \mathrm{sm}+2 \mathrm{st}+42 \mathrm{a}$ chromosomes, and a fundamental number of 86 (Figure 2).


Figure 2. Karyotype of Loricaria cataphracta stained with Giemsa. 
Analyses of the NOR by different techniques (i.e., Ag-NOR, FISH, CMA , DAPI, and $\mathrm{C}$-band) revealed five different patterns (I-V) among individuals, indicating an intra-population polymorphism in the rDNA distribution (patterns I to V; Figures 3 and 4). Most individuals examined presented a simple-NOR system, which was detected in two patterns (patterns I and II; Figures 3 and 5). In pattern I, NOR sites were observed in the interstitial position of the long arm of the first pair of acrocentric chromosomes (pair 12; Figure 5), whereas in pattern II, the NOR was detected near the centromeric region on the long arm of the medium-sized submetacentric chromosome (pair 8; Figure 5). In addition, three other patterns with multiple-NOR systems were observed (III, IV, and V; Figures 4 and 5). In pattern III, the NOR was evident in only one of the homologs in pairs 12 and 8 (Figure 5). In other patterns, the NOR was also detected in pair 12 (same as pattern I), but additional NOR sites were located in one of the homologs of a submetacentric chromosome, pair 9 (pattern IV; Figure 5) and an acrocentric chromosome, pair 13 (pattern V; Figure 5). Fluorescent $\mathrm{CMA}_{3}$ bands were observed coincident with Ag-NOR signatures, which, in contrast, showed negative DAPI staining. C-banding analysis revealed that all NORs were heterochromatic (positive C-band), thus characterizing a polymorphism of constitutive heterochromatin distribution (Figures 3, 4, and 5).

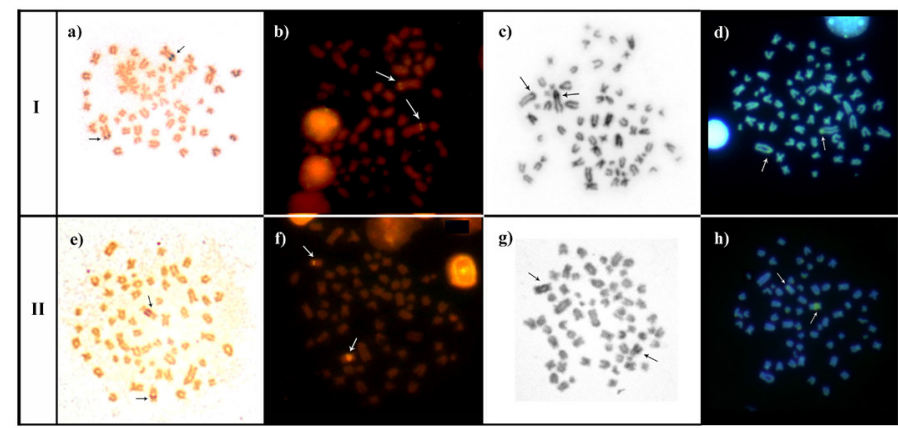

Figure 3. Somatic metaphases of Loricaria cataphracta, patterns I and II with simple-NOR system: (a), (e) AgNOR; (b), (f) FISH; (c), (g) C-band, and (d), (h) $\mathrm{CMA}_{3}$ /DAPI. Arrows indicate rDNA sites.



Figure 4. Somatic metaphases of Loricaria cataphracta, patterns III, IV and V with multiple-NOR system: (a), (e), (i) Ag-NOR; (b), (f), (j) FISH; (c), (g) (k) C-band, and (d), (h), (l) CMA /DAPI. The arrows indicate the sites. 


\begin{tabular}{|c|c|c|c|c|c|c|c|c|c|c|c|c|c|c|c|}
\hline \multirow[t]{2}{*}{ Patterns } & \multicolumn{4}{|c|}{ Ag-NOR } & \multicolumn{4}{|c|}{ FISH (18S rDNA) } & \multicolumn{4}{|c|}{$\mathrm{CMA}_{3} / \mathrm{DAPI}$} & \multicolumn{3}{|c|}{ C-Band } \\
\hline & 8 & 9 & 12 & 13 & 8 & 9 & 12 & 13 & 8 & 9 & 12 & 13 & 8 & $\begin{array}{ll}9 & 12 \\
\end{array}$ & 13 \\
\hline I & & & ef & & & & 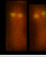 & & & & 10 & & BA & s. 18 & AA \\
\hline II & 6ี & & & & 6 & & & & ent & & & & 8. & as 1 & 욜요 \\
\hline III & $\hbar_{2}$ & & 8 & & $t_{-}$ & & 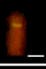 & & $8 \mathrm{n}$ & & A & & A &  & 98 \\
\hline IV & & & if & & & 0 & Af & & & $\mathbf{x}_{-}$ & Af & & 18 & 91 & 10 \\
\hline $\mathbf{v}$ & & & i* & 8 & & & 98 & is & & & 01 & $e$ & as &  & 98 \\
\hline
\end{tabular}

Figure 5. Chromosomes that showed NOR sites in Loricaria cataphracta, detected in patterns I-V by the techniques Ag-NOR, FISH (18S rDNA probes), $\mathrm{CMA}_{3}$, DAPI, and C-band.

\section{DISCUSSION}

Few cytogenetic studies have been conducted on the genus Loricaria, which shows variation in chromosome numbers ranging from $2 n=52$ in Loricaria sp (Oliveira et al., 1998) to $2 \mathrm{n}=64$ in L. cataphracta (Roncati et al., 1999; this study) and Loricaria sp (Scavone and Júlio-Jr., 1994), and a high number of acrocentric chromosomes. Therefore, the diploid number $(2 \mathrm{n}=64)$ found in the present study corroborates with previous data from L. cataphracta and other species of the Loricaria genus.

Simple NORs have been reported in most species of the family Loricariidae, and is therefore considered to be a plesiomorphic feature of this group (Artoni and Bertollo, 1996). Simple NORs have also been detected in many of the species of the Loricariinae subfamily, whereas only one population of $R$. pentamaculata (Porto et al., 2011) and one population of $R$. lanceolata (Porto, 2012) showed a multiple-NOR system.

In the present study, both simple- and multiple-NOR systems were observed, demonstrating a polymorphism of NORs with five patterns detected (I, II, III, IV, and V). Preferential NOR sites, which were present in most of the patterns (except for pattern II), were detected in at least one of the homologs of pair 12 (Figure 5). Thus, in most individuals, NOR sites of chromosome pair 12 remained constant, and was therefore considered to be the main nucleolar organizer for the population.

Polymorphisms of the NOR are relatively common in fish, especially in the Salmonidae and Characidae families, which show both intra- and inter-individual variation of these regions (Galetti Jr., 1998; Castro et al., 1996, 2001; Jankun et al., 2001; Santi-Rampazzo et al., 2008). Although inter-individual variations of NORs are considered to be relatively rare in fish, some have been identified in Leporinus friderici (Galetti Jr. et al., 1995), Serrapinnus notomelas (Santi-Rampazzo et al. 2008), in the genus Symphysodon (Gross et al., 2010), $R$. lanceolata (Porto, 2012), and in L. cataphracta (present study).

Some events have been suggested to explain NOR variations in the fish karyotype, including the occurrence of post-zygotic modifications involving these chromosome sites (Galetti Jr. et al., 1995) and the presence of transposable elements adjacent to ribosomal genes, which may have caused dispersal of these genes throughout the genome (Santi-Rampazzo et al., 2008; Ferreira et al., 2011). 
Sequences that are similar to transposable elements, such as mariner-like elements, have been identified in fish, and have been associated with NORs in Gobius niger (Mandrioli et al., 2000) and Tetraodon fluviatilis (Mandrioli and Manicardi, 2001). In invertebrates, transposable elements that are associated with specific regions of the genome may contribute to inactivation of this gene, such as long interspersed elements associated with rRNA (28S) in Drosophila melanogaster (Eickbush and Furano, 2002).

An analysis of NORs in $S$. notomelas revealed an intra-population polymorphism classified into six different patterns, with pattern I corresponding to the presence of ribosomal sites in a single-nucleolar pair (Santi-Rampazzo et al., 2008). These authors suggested that this was due to transposition of rDNA genes from this main pair to other sites in the genome. Similarly, L. cataphracta has a main nucleolar pair (pair 12), suggesting that rDNA genes are likely associated with mobile transposable elements. Additional NOR sites may be found in different chromosome types, as observed in patterns III, IV, and V. These results might reflect the transposition of rDNA genes located on pair 12 into different places in the genome (pairs 8,9 and 13). However, the absence of the main nucleolar pair in pattern II might also indicate that other mechanisms are involved, in which ribosomal genes were instead cleaved and removed from pair 12 to another site in the genome (pair 8). Therefore, these transpositions may be due to sending copies of rDNA genes and/or cleavage removal and reinsertion into sites that have sequences that are homologous with the inserts.

The NORs revealed a positive C-band, and consequently, polymorphisms involving constitutive heterochromatin were also detected (Figures 3 and 4), confirming the various patterns described in this study. It is possible that constitutive heterochromatin, which flanks the rDNA, follows these genes regardless of the mechanism involved in driving this variation. C-band variations associated with NORs have also been observed in S. notomelas (Santi-Rampazzo et al., 2008). Moreover, $\mathrm{CMA}_{3}$ staining revealed bright signals equivalent to NOR-bearing GC-rich chromosomal segments, and these regions were also negatively stained by DAPI. Associations of NOR sites with GC-rich sites are relatively common in fish (Artoni et al., 1999; Ráb et al., 1999).

An association between transposable elements and constitutive heterochromatin has also been observed in teleost fish. Mapping of the transposable elements Rex1, Rex3, and Rex6 in some species of fish revealed that they are preserved and compartmentalized in pericentromeric heterochromatic regions, suggesting that transposable elements are part of the structure and organization of heterochromatin (Valente et al., 2011).

Transposable elements are responsible for significant karyotypic variations in fish, including the formation of sex chromosomes, supranumerary chromosomes, associations with NORs, and in the evolution of the teleost genome (Ferreira et al., 2011).

Intra-population differences in the distribution of rDNA, such as observed in the present study, have been observed more and more frequently with increasing numbers of studies and the use of combined techniques to detect this region. Nonetheless, cytogenetic studies in the genus Loricaria remain rare. A detailed chromosomal analysis, as performed in the present study, demonstrates that mechanisms such as transposable elements, in addition to chromosomal rearrangements, can significantly contribute to the transformation of the genome during karyotype evolution of the group.

\section{ACKNOWLEDGMENTS}

We thank the Brazilian agency CAPES for financial support and Cláudio Henrique Zawadzki (UEM-NUPELIA) for identifying the specimens. 


\section{REFERENCES}

Artoni RF and Bertollo LAC (1996). Cytogenetic studies on Hypostominae (Pisces, Siluriformes, Loricariidae): Considerations on karyotype evolution in the genus Hypostomus. Caryologia 49: 81-90.

Artoni RF and Bertollo LAC (2001). Trends in the karyotype evolution of Loricariidae fish (Siluriformes). Hereditas 134: 201-210.

Artoni RF, Molina WF, Bertollo LAC and Galetti PM Jr (1999). Heterochromatin analysis in the fish species Liposarcus anisitsi (Siluriformes) and Leporinus elongates (Characiformes). Genet. Mol. Biol. 22: 39-44.

Bertollo LAC, Takahashi CS and Moreira-Filho O (1978). Cytotaxonomic considerations on Hoplias lacerdae (Pisces, Erythrinidae). Braz. J. Genet. 1: 103-120.

Castro J, Viñas A, Sánchez L and Martinez P (1996). Characterization of an atypical NOR site polymorphism in brown trout (Salmo trutta) with Ag- and CMA3-staining, and fluorescent in situ hybridization. Cytogenet. Cell Genet. 75 : 234-239.

Castro J, Rodriguez S, Pardo BG, Sanchez L, et al. (2001). Population analysis of an unusual NOR-site polymorphism in brown trout (Salmo trutta L.). Heredity 86: 291-302.

Eickbush TH and Furano AV (2002). Fruit flies and humans respond differently to retrotransposons. Curr. Opin. Genet. Dev. 12: 669-674.

Eschmeyer WN and Fong JD (2012). Species of Fishes by Family/Subfamily. On-line Version Dated 29/05/2012. Available at [http://research.calacademy.org/research/ichthyology/catalog/SpeciesByFamily.asp.]. Accessed October 6, 2012.

Ferreira DC, Porto-Foresti F, Oliveira C and Foresti F (2011). Transposable elements as a potential source for understanding the fish genome. Mobile Genet. Elements 1: 112-117.

Galetti PM Jr (1998). Chromosome diversity in Neotropical fishes: NOR studies. Ital. J. Zool. 65: 53-56.

Galetti PM Jr, Mestriner CA, Monaco PJ and Rasch EM (1995). Post-zygotic modifications and intra- and inter-individual nucleolar organizing region variations in fish: report of a case involving Leporinus friderici. Chromosome Res. 3 : 285-290.

Giuliano-Caetano L (1998). Polimorfismo Cromossômico Robertsoniano em Populações de Rineloricaria latirostris (Pisces, Loricariinae). Doctoral thesis, Universidade Federal de São Carlos, São Carlos.

Gross MC, Schneider CH, Valente GT, Martins C, et al. (2010). Variability of 18S rDNA locus among Symphysodon fishes: chromosomal rearrangements. J. Fish Biol. 76: 1117-1127.

Howell WM and Black DA (1980). Controlled silver-staining of nucleolus organizer regions with a protective colloidal developer: a 1-step method. Experientia 36: 1014-1015.

Jankun M, Martinez P, Pardo BG, Kirtiklis L, et al. (2001). Ribosomal genes in Coregonid fishes (Coregonus lavaretus, C. albula and C. peled) (Salmonidae): single and multiple nucleolus organizer regions. Heredity 87: 672-679.

Levan A, Fredga K and Sandberg AA (1964). Nomenclature for centromeric position on chromosomes. Hereditas 52: 201-220.

Mandrioli M and Manicardi GC (2001). Cytogenetic and molecular analysis of the pufferfish Tetraodon fluviatilis (Osteichthyes). Genetica 111: 433-438.

Mandrioli M, Manicardi GC, Machella N and Caputo V (2000). Molecular and cytogenetic analysis of the goby Gobius niger (Teleostei, Gobiidae). Genetica 110: 73-78.

Oliveira ASS, Souto PSS, Pauls E and Matos E (1998). Estudos Citogenéticos em Loricaria sp. (Pisces, Loricariidae) Rio Jari, Município de Almeirim, Estado do Pará. XXII Congresso Brasileiro de Zoologia, 222.

Pinkel D, Straume T and Gray JW (1986). Cytogenetic analysis using quantitative, high-sensitivity, fluorescence hybridization. Proc. Natl. Acad. Sci. U. S. A. 83: 2934-2938.

Porto FE (2012). Diversidade Cromossômica em Duas Espécies da Subfamília Loricariinae (Siluriformes, Loricariidae) da Bacia do Rio Paraguai, MS, Doctoral thesis, Universidade Estadual de Maringá, Maringá.

Porto FE, Portela-Castro ALB and Martins-Santos IC (2011). Chromosome polymorphism in Rineloricaria pentamaculata (Loricariidae, Siluriformes) of the Paraná River basin. Ichthyol. Res. DOI 10.1007/s10228-011-0215-5.

Ráb P, Rábová M, Reed KM and Phillips RB (1999). Chromosomal characteristics of ribosomal DNA in the primitive semionotiform fish, longnose gar Lepisosteus osseus. Chromosome Res. 7: 475-480.

Reis RE, Pereira EH and Armbruster LJW (2006). Delturinae, a new loricariid catfish subfamily (Teleostei, Siluriformes), with revisions of Delturus and Hemipsilichthys. Zool. J. Linn. Soc. 147: 277-299.

Roncati HA, Corio C, Malone G, Fenocchio AS, et al. (1999). Relevamiento Citogenetico en Peces del Rio Paraná (Argentina). VII Subfamílias Loricariinae e Hypostominae (Pisces, Siluriformes, Loricariidae). Genet. Mol. Biol. 22: 82.

Santi-Rampazzo AP, Nishiyama PB, Ferreira PEB and Martins-Santos IC (2008). Intrapopulational polymorphism of 
nucleolus organizer regions in Serrapinnus notomelas (Characidae, Cheirodontinae) from the Paraná River. J. Fish Biol. 72: 1236-1243.

Scavone MDP and Júlio-Jr HF (1994). Cytogenetic analysis and probable supernumerary chromosomes of Loricaria prolixa and Loricaria sp. females (Loricariidae-Siluriformes) from the Paraná river basin. Rev. Ictiol. 2-3: 41-47.

Schweizer D (1980). Simultaneous fluorescent staining of R bands and specific heterochromatic regions (DA-DAPI bands) in human chromosomes. Cytogenet. Cell Genet. 27: 190-193.

Sumner AT (1972). A simple technique for demonstrating centromeric heterochromatin. Exp. Cell Res. 75: 304-306.

Thomas MR and Rapp Py-Daniel LH (2008). Three new species of the armored catfish genus Loricaria (Siluriformes:Loricariidae) from river channels of the Amazon basin. Neotrop. Ichthyol. 6: 379-394.

Thomas MR and Pérez MHS (2010). A new species of whiptail catfish, genus Loricaria (Siluriformes: Loricariidae), from the Curuá river (Xingu Basin), Brazil. Copeia 2: 274-283.

Valente GT, Mazzuchelli J, Ferreira IA, Poletto AB, et al. (2011). Cytogenetic mapping of the retroelements Rex1, Rex3 and Rex6 among cichlid fish: new insights on the chromosomal distribution of transposable elements. Cytogenet. Genome Res. 133: 34-42. 